\title{
Which came first: the money or the rank?
}

\author{
Athanassios C. Tsikliras ${ }^{1, *}$, David Robinson ${ }^{2}$, Konstantinos I. Stergiou ${ }^{1,3}$ \\ ${ }^{1}$ Laboratory of Ichthyology, Department of Zoology, School of Biology, Aristotle University of Thessaloniki, UP Box 134, \\ 54124 Thessaloniki, Greece \\ ${ }^{2}$ Education International, 5 blvd du Roi Albert II, 1210 Brussels, Belgium \\ ${ }^{3}$ Institute of Marine Biological Resources and Inland Waters, Hellenic Centre for Marine Research, \\ Aghios Kosmas, 16777 Athens, Greece
}

\begin{abstract}
Global university rankings are provided by several organisations based on various criteria, most of which are, directly or indirectly, related to the wealth of the university. The main objective of this work was to examine the effect of money on rankings and vice versa. First, we examined the relationship between global university rankings and professors' salaries and found an asymptotic trend for all ranks of professors across the top 200 US universities, but no trend for the top Canadian universities. Second, we examined the relationship between global university rankings and university income and found a positive trend for UK and Canadian universities. Our results are consistent with the hypothesis that the funding (as well as autonomy and support of the state) of a university and its position in global rankings are related. We maintain that European universities in several countries will not make it into the top 100 list unless their autonomy and public funding are increased. Instead, the recent decrease in public funding of universities in many European countries, as a result of the economic crisis, threatens to push these institutions further down the ranking lists.
\end{abstract}

KEY WORDS: University rankings $\cdot$ Income $\cdot$ Professor salary $\cdot$ Endowments $\cdot$ Funding

\section{INTRODUCTION}

Academia's obsession with measuring quantifiable outputs (Fischer et al. 2012) extends back to at least the 1960s, when the Science Citation Index was established for evaluating the impact of scientific journals (Stergiou \& Lessenich 2013 this Theme Section). Several jurisdictions developed more sophisticated measures of research productivity and institutional performance, with the first emergence of university and college rankings at the national level in the 1980s (Lynch 2013 this Theme Section; see also Caplow \& McGee 1958). However, global university ranking systems are a more recent phenomenon, first appearing in 2003 with the publication of the Shanghai league table - now known as the Academic Ranking of World Universities, ARWU (Rauhvargers 2011, 2013). Since then, global rankings have received increasing attention from the public, media, students, administrators and professors. In response to their growing popularity, more ranking systems have been established, including the most widely used ones: the Times Higher Education (THE), Webometrics (WM) and Quacquarelli Symonds (QS) ranking systems (Jarocka 2012). In addition, regional and national ranking systems now exist for European, Asian, North and South American and Oceania countries, and new ranking systems are being developed, such as the Umultirank, which is supported by the European Union (EU) (Rauhvargers 2011, 2013, Jarocka 2012).

Global university ranking systems use various criteria to produce their league tables (Enserink 2007, Salmi \& Saroyan 2007, Usher \& Savino 2007), including: individual scientific performance of academic staff (e.g. total number of papers, publications in top journals); scientific recognition (e.g. number of citations); employer and peer reputation; the number of international staff and students; admissions policy; and even the number of Nobel Prize winners among their staff and alumni. Many of the current criteria for 
the 4 main rankings systems (ARWU, THE, WM, QS) appear to be, directly or indirectly, related to the wealth of an institution, including total university revenues and salaries of staff (Table 1). Thus, one can hypothesize that, to attract scientists fulfilling the criteria of rankings that will lead to improved positions in the league table, universities will have to adopt market strategies to increase their wealth (Robinson 2013 this Theme Section). The wealthier an institution, the more it is able to pay higher salaries to attract staff, enhance its reputation profile, facilitate student recruitment, and draw more research funding, and other benefits, to raise their position in the rankings (Lim \& Boey 2014 this Theme Section). As Hazelkorn (2009) suggests, perhaps rankings are best seen as reflections of the relative wealth of various institutions.

Herein, we explore the hypotheses that there is a relationship between rank and salary and between rank and income among universities, using data for US and Canadian universities (for professors' salaries) and Canadian and UK universities (for various sources of income). Based on these relationships, we attempt to explain the unequal representation of North American and European universities in the top 100 of the rankings (Aghion et al. 2007).

\section{DO TOP-RANKED UNIVERSITIES PAY HIGHER SALARIES?}

To examine the higher rank vs. higher salary hypothesis, we collected data on mean annual salaries of assistant, associate and full professors from the top 200 US universities and their corresponding national ranking. Salaries were downloaded from http:// chronicle.com/article/Interactive-Table-Average/ 131433/, whereas for the ranking of the corresponding universities we used the QS ranking system (data for 2012 to 2013: www.topuniversities.com/ university-rankings/world-university-rankings/2012) because it provides university ranking in numbered positions down to 500. We also collected data on the mean salaries of assistant, associate and full professors from the 18 Canadian universities (salaries were downloaded from Statistics Canada 2012) that appear in the top 500 of the QS 2012-2013 list.

For every professor rank in US universities, the salaries of the professors were strongly related $(\mathrm{p}<$ 0.05 ) to university rankings, clearly showing that highly ranked universities pay higher salaries (Fig. 1a). The shape of the curve indicates a common bottom salary for many universities per rank, whereas the curve levels off for higher salaries.

The slope of the line between salary and rank declines from assistant to full professors (Fig. 1a), indicating that highly ranked universities invest in younger faculty at the crucial early stages of their careers, i.e. paying more to attract promising early career faculty. In addition, what is also evident from Fig. 1 is the large variation in salaries per staff rank, with salaries ranging from 57000 to 112300 US \$ for assistant professors (mean $\pm \mathrm{SE}=75857 \pm 811$ US \$) for Bowling Green State University and University of Pennsylvania, respectively; from 67600 to 131200 US \$ for

Table 1. The criteria employed by the main university ranking lists. ARWU: Academic Ranking of World Universities (www. shanghairanking.com/ARWU-Methodology-2011.html); THE: Times Higher Education World University Rankings (www. timeshighereducation.co.uk/411907.article); QS: QS World University Rankings (www.iu.qs.com/university-rankings/worlduniversity-rankings/); WM: Webometrics Ranking of World Universities (www.webometrics.info/en/Methodology)

\begin{tabular}{|c|c|c|c|c|}
\hline Criterion & ARWU & THE & QS & WM \\
\hline Articles published in Nature and Science & $20 \%$ & & & \\
\hline Articles indexed in Science Citation Index & $20 \%$ & & & \\
\hline Alumni winning Nobel Prize and Fields Medal & $10 \%$ & & & \\
\hline Staff winning Nobel Prize and Fields Medal & $20 \%$ & & & \\
\hline Highly cited researchers & $20 \%$ & & & \\
\hline Per capita academic performance & $10 \%$ & & & \\
\hline Academic reputation (global survey) & & & $40 \%$ & \\
\hline Employer reputation (global survey) & & & $10 \%$ & \\
\hline Citations per faculty member (Scopus) & & & $20 \%$ & \\
\hline Faculty/student ratio & & & $20 \%$ & \\
\hline International staff and students & & $10 \%$ & $10 \%$ & \\
\hline Research income from industry & & $10 \%$ & & \\
\hline Research indicators (papers, citations, income, reputation) & & $55 \%$ & & \\
\hline Institutional indicators (admissions, $\mathrm{PhD}$ students, teaching reputation) & & $25 \%$ & & \\
\hline Web presence, visibility and access & & & & $\checkmark$ \\
\hline
\end{tabular}




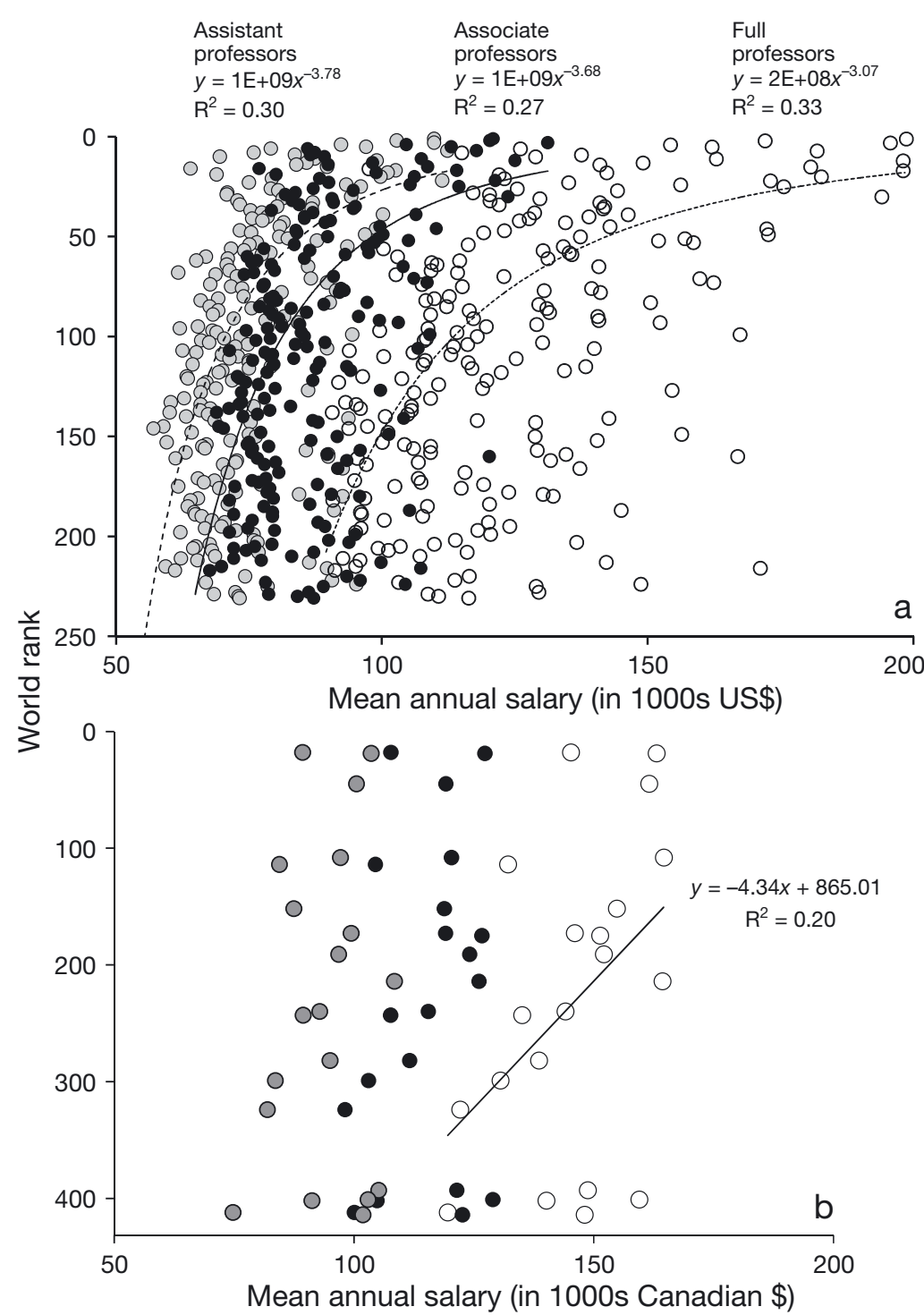

Fig. 1. Relationship between mean annual salary of (a) US (in US dollars) and (b) Canadian (in Canadian dollars) university professors and the global rank of the university they work at (white dot: full professors, black dot: associate professors, grey dot: assistant professors). Salary data for the US are from http://chronicle.com/article/Interactive-Table-Average/ 131433/, and for Canada from www.statcan.gc.ca/reference/copyrightdroit-auteur-eng.htm. Ranking data are according to QS

universities in the top 500 is relatively low $(<20)$ and the range of the salaries per professor rank is narrow. For the 18 Canadian universities, the mean salaries of assistant, associate and full professors were 93 959, 115340 and 146059 Canadian $\$$, respectively. The mean salaries per professor rank in top Canadian universities ranged less than the US ones (professors: from 119523 to 164570 Canadian \$, for University of Quebec and University of Calgary, respectively; associate professors: from 98115 to 128898 Canadian \$, for Laval University and York University, respectively; assistant professors: from 74713 to 108393 Canadian \$, for Quebec and Calgary, respectively). Unlike in the US, almost all universities in Canada are publicly funded ${ }^{1}$ by provincial governments and nearly all faculty in Canada are covered by negotiated collective agreements that set common pay scales limiting variations in compensation within and between institutions (Robinson 2006). Universities still have considerable flexibility to place individual faculty higher on the salary grid and reward them with various pay supplements, but when compared with the US, there is greater pay equality among Canadian institutions and a relatively higher salary for professors working at lower-ranked universities. This can have the effect of spreading talent wider (Dehaas 2012) across Canadian institutions. The combination of public funding and high faculty union density rates in Canada contributes to creating comparable levels of quality across the system and across regions, as opposed to the US where funding is far more fragmented and resources, particularly with respect to research, are far more concen-

associate professors (mean $\pm \mathrm{SE}=87462 \pm 903$ US \$), for Indiana State University and Stanford University, respectively; and from 90300 to 198400 US \$ for full professors (mean $\pm \mathrm{SE}=124585 \pm 1710$ US \$) for the University of Idaho and Harvard University, respectively. Given that the salaries used here are mean salaries for each university, the actual range of individual salaries is expected to be higher.

In contrast, for the Canadian Universities, no such relationships were found (Fig. 1b). This is probably because-compared with the US - the number of trated. As with funding (Fortin \& Currie 2013), this suggests that strategies and practices that target diversity and quality across a system rather than concentrate resources to support the 'excellence' of a few institutions may prove more productive.

\footnotetext{
${ }^{1}$ While it is true that all Canadian universities receive public funding, private sources of funding (mainly tuition fees) now make up between 35 and $50 \%$ of revenues and research funding is highly concentrated.
} 
Gaps between US and Canadian faculty salaries are observed at the higher-ranked institutions. According to a recent book on professors' salaries (Altbach et al. 2012), the average of professors' salaries in the US, when scaled per standard of living, are below the salaries of other countries, such as in Canada (which tops), Italy and South Africa. However, the situation may totally differ if only the salaries of the top universities are included, because the top US universities pay up to $70 \%$ higher salaries than the country average. The ranking-salary relationship and the wide range of salaries per staff rank in the top US universities certainly reflect the market aspects of the US top universities, which adopt recruitment and retention strategies employed by other industries (e.g. sports) by offering 'star' candidates high salaries, substantial research support, and a range of other monetary and fringe benefits. What is not certain from the ranking-salary relationship, however, is whether highly ranked universities have the ability to pay higher salaries to maintain their position or whether they are using the high salary as a motive to attract leading scientists to climb up the list. In any case, the fact that world-class universities have abundant resources and endowments (Salmi 2009, Kaba 2012, Turner 2013 this Theme Section) indicates that they have the capability and flexibility to attract and retain the top academics and maintain their high ranking. The importance of this has been recognized by several Asian institutions that have significantly increased their budgets and enhanced their pay scales to improve their ranking position (Lim \& Boey 2014).

Although salary is a prime motivation (Weiler 1985, Lillydahl \& Singell 1993) in accepting a position in a particular university, it is not necessarily the only one. For instance, US universities are often 'attractive' to Canadian scientists because the amount of available research funding is higher than elsewhere. Many anecdotal cases involving professors changing institutions quite often involve offers of greater research funding and/or less teaching workload. Other factors, such as job satisfaction, relationships between colleagues (Manger \& Eikeland 1990), and cultural and lifestyle reasons, might also play a role in accepting a position in a particular university.

\section{DO HIGHLY RANKED UNIVERSITIES GET MORE FUNDING?}

To examine the highly ranked vs. higher income hypothesis, we downloaded the financial data (annual total income, net assets, funding council grants, research grants and contracts, other income, endowment and investment income, staff cost, European tuition fees, overseas fees, staff cost over total income and total borrowing cost) of the top $45 \mathrm{UK}$ universities (all data in British pounds) from Times Higher Education (www.timeshighereducation.co. uk/Journals/THE/THE/12_April_2012/attachments/ financial_data.pdf), and their corresponding world ranking from QS (data for 2012 to 2103: www.topuniversities.com/university-rankings/world-universityrankings/2012).

We also collected the sponsored research income, number of full time faculty and research funding per full time faculty for 2010 to 2011 (data were taken from Statistics Canada 2012) for the 20 Canadian universities that appear in the top 500 of the QS 2012-2013 list.

For UK universities, total university income (i.e. research income, council grants, income from admission fees, endowments and investments) was significantly $(\mathrm{p}<0.05)$ positively related to the university ranking following a power function (Fig. 2a). The same relationship was observed for university ranking with net assets (Fig. 2b), funding council grants (Fig. 2c), research grants and contracts (Fig. 2d), overseas tuition fees (Fig. 2f), other income (Fig. 2g), endowment and investment income (Fig. 2h) and total staff cost (Fig. 2i). European tuition fees also significantly $(p<0.05)$ increased with rank, but linearly (Fig. 2e). Staff cost over total income (Fig. 2j) and total borrowing cost (Fig. 2k) were the 2 exceptions that were not related to university ranking $(p>0.05)$.

For Canadian universities, total sponsored research funding (Fig. 3a), the number of full time faculty (Fig. 3b) and research funding per full time staff (Fig. 3c) were all significantly $(p<0.05)$ related to university ranking. The relationships were logarithmic or exponential.

The relationships shown in Figs. 2 \& 3 indicate that there is a strong correlation between rankings and the total wealth of a university. An advantage of a high rank (regarded by the public as equivalent to high reputation) for a university is that according to the supply-demand market law it can increase its overseas and postgraduate tuition fees (domestic undergraduate tuition fees are regulated in the UK and Canada) and ancillary fees because it receives more applications. At the same time, a highly ranked university may more easily attract competitive public and private funding, particularly with respect to sponsored research. 

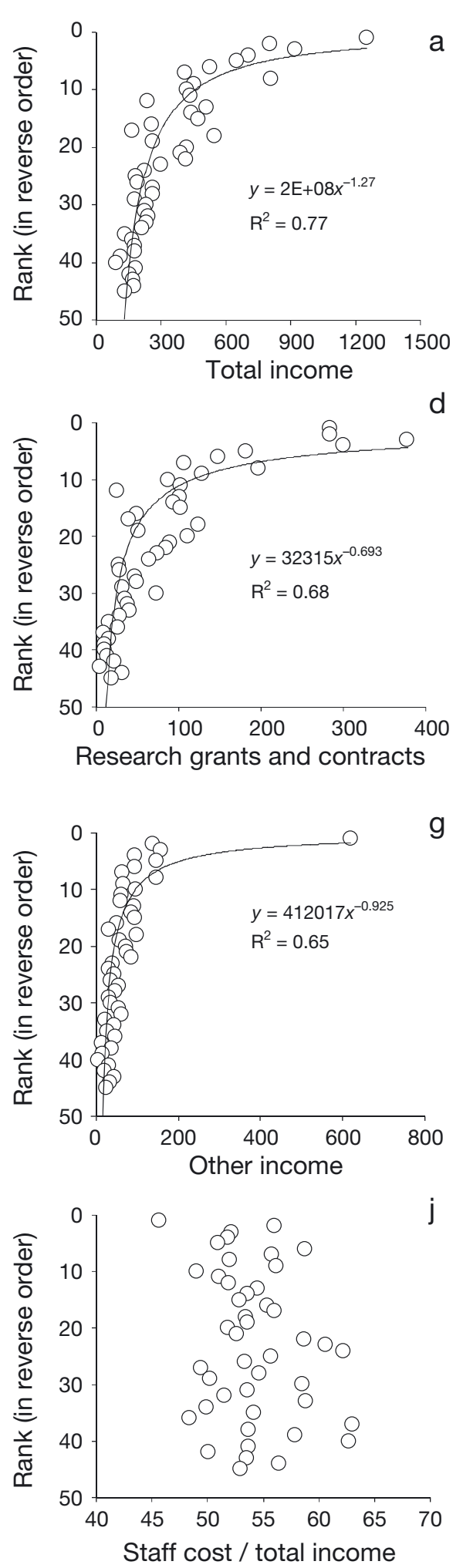

9
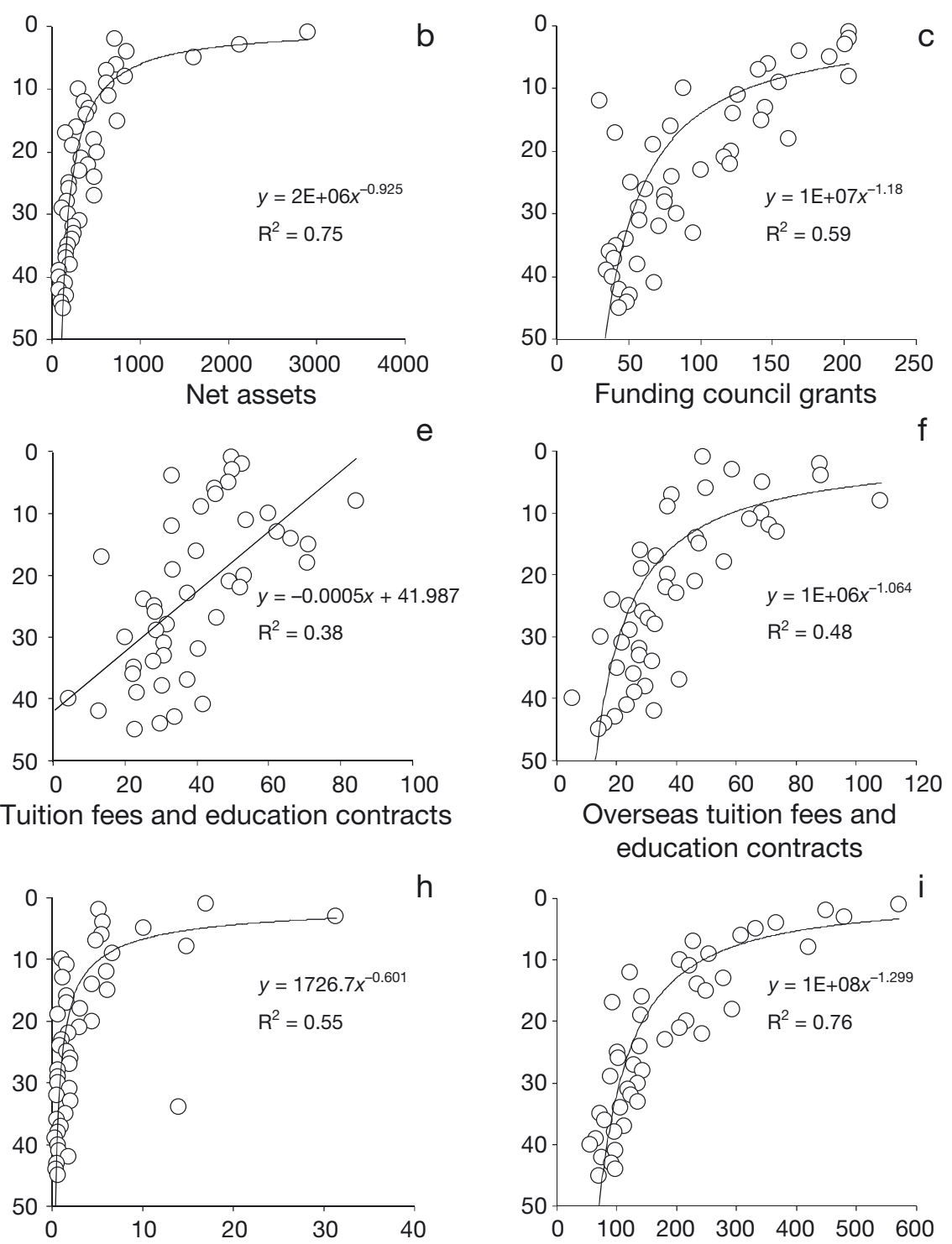

Endowment and investment income

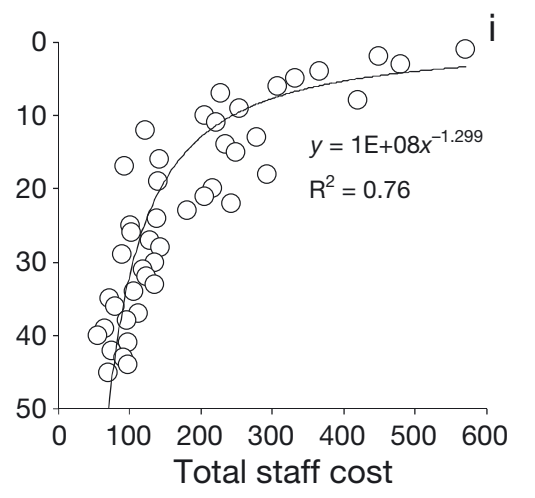

Fig. 2. The relationship between (a) annual total income, (b) net assets, (c) funding council grants, (d) research grants and contracts, (e) tuition fees, (f) overseas fees, (g) other income, (h) endowment and investment income, (i) total staff cost, (j) staff cost over total income and $(\mathrm{k})$ total borrowing cost (all absolute values in millions of British pounds, except total borrowing which is in thousands of pounds) of the top 45 UK universities and the corresponding national rank of the university. Income and cost data are from www.timeshighereducation.co.uk/Journals/THE/THE/12_April_2012/attachments/financial_data.pdf, and ranking 

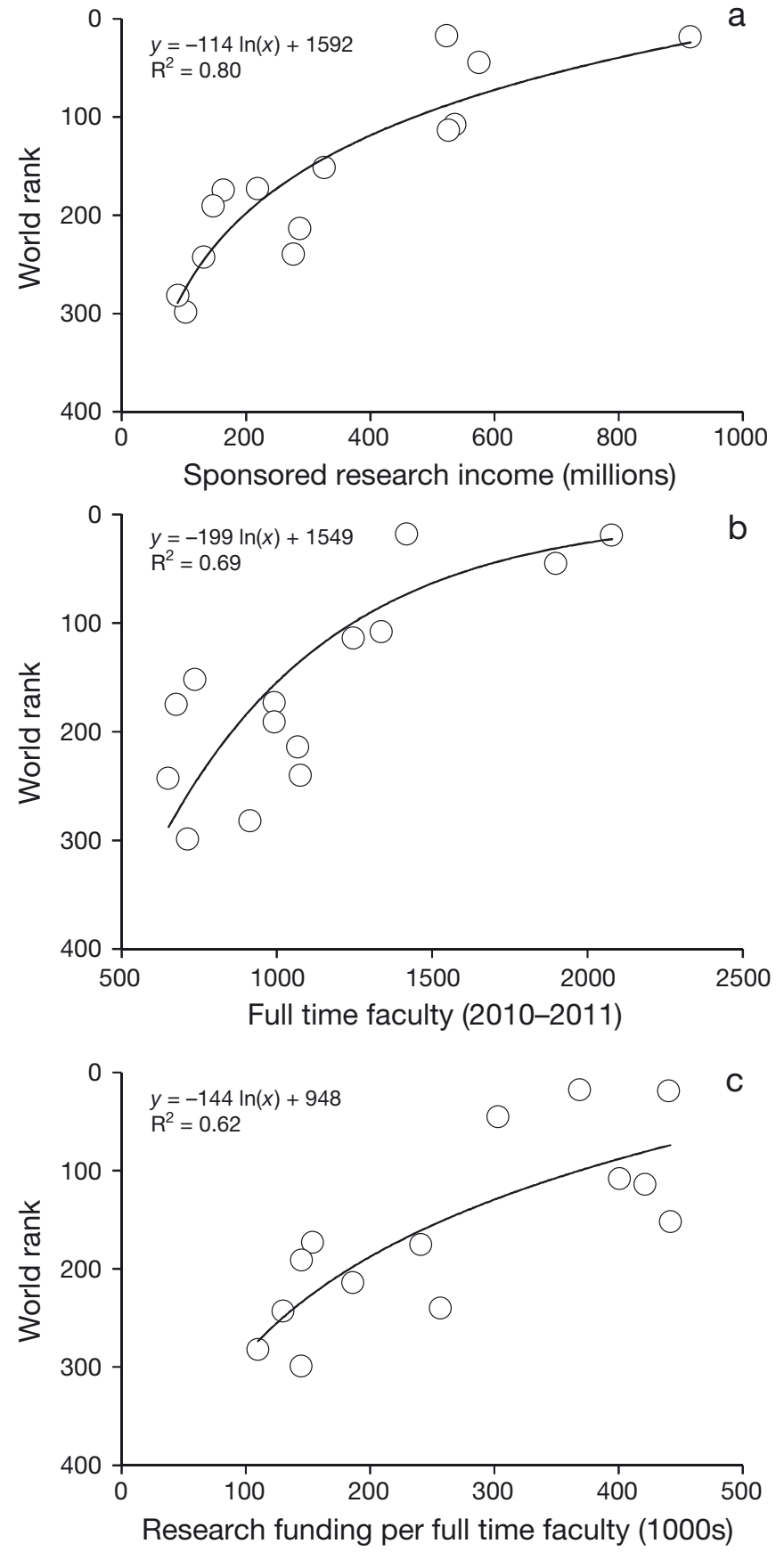

Fig. 3. Relationship between (a) sponsored research income, (b) number of full time faculty and (c) research funding per full time faculty (all in Canadian dollars) of the top Canadian universities and the corresponding world rank of the university. Income data are from Canada Statistics (2012), and ranking data are according to $\mathrm{QS}$

\section{EUROPEAN VS. NORTH AMERICAN REPRESENTATION IN THE RANKING LISTS}

In general, European universities have a limited representation in the top positions when compared with the US ones, even after scaling with population sizes (Aghion et al. 2007). For instance, according to the WM and THE lists for 2012, in the top 100 universities there are 53 and 54 US universities, respectively (Table 2). Apart from them, in the WM list, there are 5 universities from Australia, 4 from Canada, 4 from Japan and 34 European universities. Similar results are given by the THE ranking, in which more Asian universities are included in the top 100 (Table 2). In fact, even historical and established universities, such as the Italian universities of Bologna, Naples and Padua, the Spanish universities of Salamanca, Valladolid and Murcia, the Portuguese University of Coimbra and the French universities of Toulouse and Montpelier, which are among the oldest in the world and carry a heavy educational heritage, do not appear in the top 100 positions ${ }^{2}$ (Stergiou \& Tsikliras 2013 this Theme Section).

Aghion et al. (2007) examined, based on the 2006 Shanghai rankings and scaled by population size, the university performance of the US, Canada, Australia, Japan and several EU and other European countries. They report a positive relationship between country performance in rankings and amount spent on higher

Table 2. The number of universities per country that are included in the top 100 of 2 of the rankings systems (Webometrics and Times Higher Education for 2012)

\begin{tabular}{|lcc|}
\hline Country & Webometrics & Times Higher Education \\
\hline USA & 53 & 54 \\
UK & 9 & 11 \\
Australia & 5 & 4 \\
Canada & 4 & 4 \\
Germany & 4 & 4 \\
Japan & 4 & 2 \\
Switzerland & 4 & 2 \\
China & 0 & 3 \\
France & 3 & 4 \\
Israel & 3 & 0 \\
Sweden & 3 & 2 \\
Denmark & 2 & 0 \\
Netherlands & 2 & 4 \\
Hong Kong & 0 & 2 \\
Belgium & 1 & 1 \\
Finland & 1 & 1 \\
Norway & 1 & 0 \\
South Korea & 0 & 1 \\
Singapore & 0 & 1 \\
Russia & 1 & 0 \\
\hline
\end{tabular}

2 Of these 9 old universities, only the University of Bologna is found in the top 200 QS 2012 to 2013 and the universities of Toulouse and Montpelier in the top 500 QS 2012 to 2013 (Stergiou \& Tsikliras 2013). 
education per student, which agrees with our results on the relationship between funding and university rankings in the UK and Canada. Based on this relationship and the fact that, on average, the total public and private spending on higher education in the EU25 accounts for about $1.3 \%$ of gross domestic product (GDP) (i.e. $<10000$ per student), which is about one-third of that spent in the US $(3.3 \%$, $>35000$ per student), Aghion et al. (2007) maintain that lower funding is one reason explaining the relative bad performance of EU universities. Naturally, European countries are highly diversified in terms of spending on higher education (UNESCO 2000, Aghion et al. 2007, EUA 2012), a fact that is not captured when one considers the university performance of the EU25 as a whole. Denmark, Norway and Sweden have a much higher level of direct funding on higher education (as a percentage of GDP) than other countries (by $>30 \%$ ), whereas southern European countries, notably Spain, Italy and Greece, have the lowest level of direct funding (UNESCO 2000, Aghion et al. 2007, EUA 2012). This diversity in public funding is reflected in the university performance of individual European countries, with that of Denmark, Norway, Sweden, the Netherlands, Switzerland and UK being equal to or better than that of the US (Aghion et al. (2007).

There are various aspects of what makes a good university (Salmi 2009; see below), which are not necessarily related to money. Yet, the gap in public funding of higher education between several European countries and the US needs to be narrowed if European higher education institutions are to succeed (Aghion et al. 2007).

The relationship between salaries and rankings found for the top US universities (Fig. 1a) points to a second reason explaining the low representation of European universities, when compared with the US ones, in top positions - the magnitude of autonomy of European universities. Freedom in hiring and negotiation of faculty and staff salaries are important aspects of university autonomy. In the US, most universities are granted far greater control over their organizational, financial, staff and academic affairs (Aghion et al. 2007, Estermann et al. 2011) and this is well captured in the range of the salaries in the 84 top US universities. In contrast, universities in Europe are again highly diversified with respect to the freedom in setting the salaries of faculty and staff (Estermann et al. 2011). Salaries in Cyprus, Greece, Italy, Slovakia and Spain are fixed and non-negotiable (Estermann et al. 2011). Limits are placed on academic salaries in France, Hungary, Ireland, Lithua- nia, Luxembourg, Poland, Turkey, Belgium, Israel, Austria, Portugal and Germany (Estermann et al. 2011). In all of the above countries, it is mainly the rank and seniority of a professor that determines his or her salary. Salaries for senior academic staff can be negotiated in very few European countries: the Czech Republic, Estonia, Sweden, Switzerland, Denmark, Finland, Iceland, Norway, the Netherlands and the UK. Indeed, out of the 34 European universities appearing in the top WM 100 positions (Table 2) only 12 are from countries in which salaries are not negotiated (4 from Germany, 3 from France, 3 from Israel, 1 from Russia and 1 from Belgium, all at positions $>35$ ). The remaining ones are from countries (UK: 9 ; Switzerland: 4; Sweden: 3; Denmark: 2; Netherlands: 2; Norway: 1 ; and Finland: 1 ) in which the salary is negotiable (Table 2).

Canadian universities cluster together with similarly funded ${ }^{3}$ universities in Europe of similar autonomy. Thus, although as mentioned in the previous section nearly all Canadian universities are publically funded and have collective agreements, collective bargaining sets minimum salaries (which are higher than the average in the US), but administrators are free (within limits) to offer various differentials, incentives and top-ups to attract the so-called 'star' faculty. Thus, Canadian universities, like many European ones, are less represented in the top 100 when compared with ones in the US (e.g. 0.125 per million inhabitants compared with 0.187 per million inhabitants in US, based on the data from Table 2). Similarly, Aghion et al. (2007) find that universities in Canada perform worse than US ones, but better than those in the EU25 as a whole, worse than those in the UK and Switzerland, and similarly to those in Sweden, Norway, the Netherlands and Denmark.

Based on the above, it is rather unlikely that universities from countries in which salaries are not negotiated or are considerably lower than other countries will ever appear in the top 100 unless their autonomy increases, particularly in matters of collective bargaining. This is especially true for European countries with a low level of public funding on higher education. An increase in autonomy does not by any means imply that public universities will have to turn into private ones, nor does it imply that private universities should be established for some countries to be represented in the top 100 list. The privatization of

\footnotetext{
${ }^{3}$ Canada has a lower level of spending on higher education than Scandinavian countries, but higher than many other European countries (UNESCO 2000).
} 
financing and the creeping commercialization of research and teaching should be resisted, as they threaten to undermine academic freedom and distort the academic mission of universities (Robinson 2006). The increase in autonomy and, thus, an improvement in the rankings, could be achieved while maintaining the public character of universities, which we strongly support, provided that the terms and conditions of employment are improved and government funding increased. Switzerland is a good example of how this can be achieved. Swiss universities are primarily public, relatively small and very well funded, endogamy (i.e. hiring scholars with PhDs from the same institution) is low (Aghion et al. 2007) and professors' salaries are high (European University Institute 2010).

Thus, for universities (and countries) with low public funding, low or non-negotiable salaries and limited staffing autonomy, the public discussion and question of university rankings are meaningless, unless governments are willing to commit sufficient resources. Considering these criteria, public discussions on university rankings serve purposes other than improving the quality of education and research (i.e. to increase newspaper circulation: Lynch 2013; governmental driven devaluation of public universities per se to prepare the ground for the privatization and marketization of public universities: Stergiou \& Tsikliras 2012). To draw an analogy, an amateur basketball team from a small town with no budget at all cannot expect, and, more importantly, cannot be expected by their fans, to make it to the final 4 of the Euroleague basketball.

\section{INSIGHTS}

Naturally, our analysis suffers from certain limitations. In particular, our dataset is restricted with respect to the number of countries examined (i.e. funding data refer only to the UK and Canada, and salary data refer only to the US and Canada) and type of data used for funding (UK: total funding, Canada: research income). This poses limitations in drawing conclusions, especially so when one tries to explain the different position of North American and European universities. Yet, it is rather intriguing to examine the different hypotheses put here, even based on just a selection of a few systems, and raise various issues and predictions, some of which are described in the sections that follow. Other questions (e.g. the effect of provincial funding in Canada, the relationship between universities' rankings and total funding across all countries, the effect of factors other than money on rankings) will remain open to be tested in future studies.

\section{Funding, rankings and the economic crisis in Europe}

The causal link between increased funding and increased university rank postulated here would require observations of a government deciding to change funding and subsequent changes in rankings. This situation can be very well approximated by the recent sharp decrease in public funds for higher education in the southern European countries hit by the economic crisis.

Between 2008 and 2013, Portugal, Spain, Italy and Greece have seen their public funding for higher education (and research) cut by much more than $10 \%$ (EUA 2012, 2013). Greece, which since 2007 has stopped publishing figures on state funding of higher education, holds the record with an almost $50 \%$ cut in public funds (Stergiou \& Tsikliras 2012), and university and research funding being lower than $0.6 \%$ of the GDP (Trachana 2013). Such severe cuts have brought about adverse changes in many aspects related to the quality of higher education: staff numbers have been reduced, leading to decreasing staff/student ratios and increased workload for remaining staff, closing down of degree programs, reductions in the number of hours libraries are open, staff salary freezes and cuts and cuts in staff benefits (EUA 2012). All these changes have further deepened the already existing differences between the southern and the northern and western European

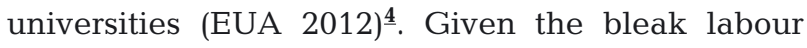
market in the sector for the foreseeable future, there has been (and will be) a continuing scientific migration of scientists from these countries (the so called brain drain), with motivated, young scholars searching for research and teaching job opportunities elsewhere, where they will practice science with dignity (Stergiou \& Tsikliras 2012, Trachana 2013). In many

\footnotetext{
${ }^{4}$ The effect of the crisis in Greece has been so severe that 'the University of Athens, the Aristotle University of Thessaloniki and the Athens Polytechnic have been forced to halt all activities as a result of Greek ministry of education proposals to suspend unilaterally 1655 university administrative workers,' with this critically threatening higher education in Greece (www.theguardian.com/world/2013/ sep/27/greek-universities-future-under-threat, accessed 3 October 2013).
} 
cases they will migrate towards the highly ranked universities that offer big money. The continuation and intensification of the brain drain could result 'in many universities finding themselves excluded from European higher education and research cooperation for a long time' (EUA 2012, p. 8).

Based on our results, one can predict that the economic crisis in Portugal, Italy, Greece and Spain will undoubtedly bring a ratcheting down in the rankings of their universities because of the imposed austerity measures. Indeed, the number of southern European universities appearing in the top 400 QS universities declined from 19 in 2011 to 16 in 2012 to 2013 (Table 3). In addition, the rankings of the top universities in each country have dropped for 4 out of 6 universities (Table 4), whereas for Greece, which has seen the most severe cut in public funds, this decrease is very pronounced, with the top university disappearing from the list in 2012 to 2013. Taylor et al. (2014 this Theme Section) also find that the ARWU rankings of the 2 largest and oldest Greek universities have declined from 2008 to 2012 . However, the volatility of the rankings, the fact that ranking methodology changes and thus annual rankings might not be directly comparable, and the fact that the effects of the crisis will most probably become apparent in the years to come do not allow us to robustly test this prediction.

The economic crisis is spreading to other EU countries, many of which also saw decreases in public funding of higher education during 2008 to 2012 .

Table 3. Number of southern European universities appearing in the top 400 QS universities by year

\begin{tabular}{|lcccc|}
\hline & 2008 & 2009 & 2011 & $2012-13$ \\
\hline Italy & 7 & 6 & 9 & 7 \\
Spain & 2 & 6 & 8 & 8 \\
Portugal & 1 & 1 & 1 & 1 \\
Greece & 1 & 1 & 1 & 0 \\
Total & 11 & 14 & 19 & 16 \\
\hline
\end{tabular}

When funding is adjusted for inflation, only in Germany, Norway, Sweden, Austria, the Belgian Frenchspeaking community, France and the Netherlands was the funding on higher education in 2012 higher than in 2008. In contrast, in Croatia, Poland, Slovakia, Czech Republic, Hungary, Ireland, Iceland, Lithuania and the UK (England and Wales) the funding of higher education in 2012 was lower than in 2008 (EUA 2013).

Salmi (2009) wrote that there are 3 important aspects that make up a world-class university: a high concentration of talent (faculty and students), abundant resources to offer a rich learning environment and conduct advanced research, and favourable governance. According to Salmi (2009), these features encourage strategic visioning, innovation and flexibility, and enable decision-making and resource management free of bureaucracy. In other words, the support of the state and adequate public funding is critical for a country to have universities in the top positions (Horta 2009). The sharp decrease in public funds in many European countries, described above, make Salmi's (2009) conditions impossible to meet. This, combined with the small degree of autonomy in several countries, is a ticket for many European universities falling further down the league tables of university rankings. This can only (and should) be prevented if, as EUA (2012, p. 8) puts it: 'higher education funding should not be seen by European governments as expenditure but rather as an investment in Europe's future, and that increased investment in higher education and research is a way to help European countries out of the economic crisis.'

\section{Funding, salaries and technical aspects of rankings systems}

Our results also have technical repercussions related to the character of the different ranking systems. First, the relationship between university

Table 4. The annual QS ranks of the southern European universities that are ranked in the top 400, as well as the top university per country (Spain, Portugal, Italy and Greece)

\begin{tabular}{|c|c|c|c|c|c|}
\hline \multirow{2}{*}{ Country } & \multirow{2}{*}{ University } & \multirow[b]{2}{*}{2008} & \multicolumn{2}{|c|}{ - QS rank per year } & \multirow[b]{2}{*}{ 2012/13 } \\
\hline & & & 2009 & 2011 & \\
\hline Italy & University of Bologna & 194 & 176 & 183 & 194 \\
\hline Italy & Sapienza University of Rome & 206 & 206 & 210 & 216 \\
\hline Spain & Universitat Autónoma de Barcelona & & 214 & 194 & 176 \\
\hline Spain & University of Barcelona & & 172 & 176 & 187 \\
\hline Portugal & University of Coimbra & 389 & 368 & 393 & 386 \\
\hline Greece & National and Kapodistrian University of Athens & 202 & 178 & 386 & - \\
\hline
\end{tabular}


'wealth' and rankings presented here will have a stronger effect on ranking systems that use criteria directly linked to income and wealth (e.g. THE) than on those systems (e.g. QS, ARWU, WM) that use proxies and criteria measuring some form of 'output' (e.g. articles, reputation, web presence) (Table 1). Yet, criteria that measure output are also indirectly affected by (or reflect) wealth, as implied by the relationship between salaries and ranking for US universities shown here. For instance, wealthy universities in the US (and in other countries in which salaries are negotiable) can hire many top scientists and Nobel laureates, simply because they can afford to offer very high salaries and other benefits (e.g. space, research funds, positions for research assistants). This will eventually lead to an increase in articles produced in the general literature and in the highprofile journals Nature and Science, as well as to an increase in citations.

Second, our results suggest that ranking systems that use size-dependent indicators related to wealth will favor large institutes irrespective of their real productivity. In general, the importance of normalizing indicators for comparative evaluations of scientists, scientific fields and universities has been repeatedly stressed (e.g. Schubert \& Braun 1986, Zitt \& Filliatreau 2007, Leydesdorff \& Shin 2011, Saisana et al. 2011). For instance, ARWU is almost entirely based on size-dependent indicators (Saisana et al. 2011, Rauhvargers 2011, 2013), many of which, as discussed above, are indirectly related to the institute's wealth and ability to attract top scientists through high salary offers. WM also uses size-dependent indicators related to number of papers and citations. In contrast, THE mainly uses 'relative', size-independent indicators (e.g. per staff member, per student) and QS is based on a mixture of size-dependent and size-independent indicators (Rauhvargers 2011, 2013). Given the strong relationship between university wealth and rankings shown here, it is essential to scale various indicators, especially those related to productivity (e.g. number of papers, citations), to the institute's wealth (e.g. number of papers per staff per US \$). This will be a measure of the effective use of limited resources, which, as Turner (2013) maintains, might substantially change the landscape of global university rankings.

Acknowledgements. The authors thank D. Currie and 2 anonymous reviewers for their comments and suggestions that greatly improved our work.

\section{LITERATURE CITED}

Aghion Ph, Dewatripont M, Hoxby C, Mas-Colell A, Sapir A (2007) Why reform Europe's universities? Bruegel Policy Brief, Bruegel, Brussels

Altbach PG, Reisberg L, Yudkevich M, Androushchak G, Pacheco IF (2012) Paying the professoriate. A global comparison of compensation and contracts. Routledge Press, New York, NY

Caplow T, McGee RJ (1958) The academic marketplace. Basic Books, New York, NY

Dehaas J (2012) The world's highest paid professors - a surprisingly good deal. Maclean's On Campus, 12 April 2012. Available at http://oncampus.macleans.ca/ education/2012/04/12/the-worlds-highest-paid-professors-a-surprisingly-good-deal/

Enserink M (2007) Who ranks the rankers? Science 317: 1026-1028

Estermann T, Nokkala T, Steinel M (2011) University autonomy in Europe II: the scorecard. European University Association, Brussels

EUA (European University Association) (2012) EUA's public funding observatory (June 2012). Available at www.eua. be/news/13-06-14/New_EUA_Public_Funding_Observa tory_report_and_online_tool_outline_trends_in_higher_ education_funding_in_Europe.aspx

EUA (European University Association) (2013). New EUA public funding observatory report and online tool. Available at www.eua.be/news/13-06-14/New_EUA_Public_ Funding_Observatory_report_and_online_tool_outline_ trends_in_higher_education_funding_in_Europe.aspx (accessed 20 September 2013)

European University Institute (2010) Academic careers observatory. Salary comparisons. Available at www. eui.eu/ProgrammesAndFellowships/AcademicCareers Observatory/CareerComparisons/SalaryComparisons. aspx (accessed 20 Jun 2013)

Fischer J, Ritchie EG, Hanspach J (2012) Academia's obsession with quantity. Trends Ecol Evol 27:473-474

Fortin JM, Currie DJ (2013) Big science vs. little science: how scientific impact scales with funding. PLoS ONE 8: e65263

Hazelkorn E (2009) Do university rankings measure what counts? The Irish Times, 21 April 2009. Available at http:// arrow.dit.ie/cgi/viewcontent.cgi?article=1022\&context $=$ cserart

Horta H (2009) Global and national prominent universities: internationalization, competitiveness and the role of the state. High Educ 58:387-405

Jarocka M (2012) University ranking systems — from league table to homogeneous groups of universities. World Acad Sci Eng Technol 66:800-805

Kaba AJ (2012) Analyzing anglo-american hegemony in the Times Higher Education rankings. Educ Policy Anal 20: $1-49$

Leydesdorff L, Shin JC (2011) How to evaluate universities in terms of their relative citation impacts: fractional counting of citations and the normalization of differences among disciplines. J Am Soc Inf Sci Technol 62:1146-1155

> Lillydahl JH, Singell LD (1993) Job satisfaction, salaries and unions: the determination of university faculty compensation. Econ Educ Rev 12:233-243

Lim CH, Boey F (2014) Strategies for academic and research excellence for a young university: perspectives from Singapore. Ethics Sci Environ Polit 13:113-123 
Lynch K (2013) New managerialism, neoliberalism and ranking. Ethics Sci Environ Polit 13:141-153

Manger T, Eikeland OJ (1990) Factors predicting staff's intentions to leave the university. High Educ 19: 281-291

Rauhvargers A (2011) Global university rankings and their impact. Report I. European University Association, Brussels. Available at www.eua.be

Rauhvargers A (2013) Global university rankings and their impact. Report II. European University Association, Brussels. Available at www.eua.be

Robinson D (2006) The status of higher education teaching personnel in Australia, Canada, New Zealand, the United Kingdom, and the United States. Report. Education International, Brussels

Robinson D (2013) The mismeasure of higher education? The corrosive effect of university rankings. Ethics Sci Environ Polit 13:65-71

Saisana M, d'Hombres B, Saltelli A (2011) Rickety numbers: volatility of university rankings and policy implications. Res Policy 40:165-177

Salmi J (2009) The challenge of establishing world-class universities. The World Bank, Washington, DC

Salmi J, Saroyan A (2007) League tables as policy instruments: uses and misuses. Higher Educ Manage Policy 19: $24-62$

Schubert A, Braun T (1986) Relative indicators and relational charts for comparative assessment of publication output and citation impact. Scientometrics 9:281-291

Statistics Canada (2012) Culture, tourism and the Centre for Education statistics: research papers. Salaries and salary scales of full-time teaching staff at Canadian universities,

Editorial responsibility: Penny Kuhn,

Oldendorf/Luhe, Germany
2010/2011: Final Report. Catalogue no. 81-595-M, no. 97. Available at www.statcan.gc.ca/pub/81-595-m/81-595m2012097-eng.pdf

Stergiou KI, Lessenich S (2013) On impact factors and university rankings: from birth to boycott. Ethics Sci Environ Polit 13:101-111

Stergiou KI, Tsikliras AC (2012) Europe's economic crisis hits Greek universities hard. The Chronicle of Higher Education, 5 October 2012. Available at http://chronicle. com/article/Europes-Economic-Crisis-Hits/134814/

Stergiou KI, Tsikliras AC (2013) Global university reputation and rankings: insights from culturomics. Ethics Sci Environ Polit 13:193-202

Taylor M, Perakakis P, Trachana V, Gialis S (2014) Rankings are the sorcerer's new apprentice. Ethics Sci Environ Polit 13:73-99

Trachana V (2013) Austerity-led brain drain is killing Greek science. Nature 496:271

Turner DA (2013) World class universities and international rankings. Ethics Sci Environ Polit 13:167-176

UNESCO (2000). World education report 2000. The right to education: towards education for all throughout life. UNESCO Publications, Paris

Usher A, Savino M (2007) A global survey of university ranking and league tables. High Educ Eur 32:5-15

Weiler WC (1985) Why do faculty members leave a university? Res Higher Educ 23:270-278

Zitt M, Filliatreau G (2007) Big is (made) beautiful - some comments about Shanghai-ranking of world-class universities. In: Sadlak J, Cai LN (eds), The world-class university and ranking: aiming beyond status. UNESCOCEPES, Bucharest

Submitted: July 9, 2013; Accepted: December 9, 2013 Proofs received from author(s): March 7, 2014 